
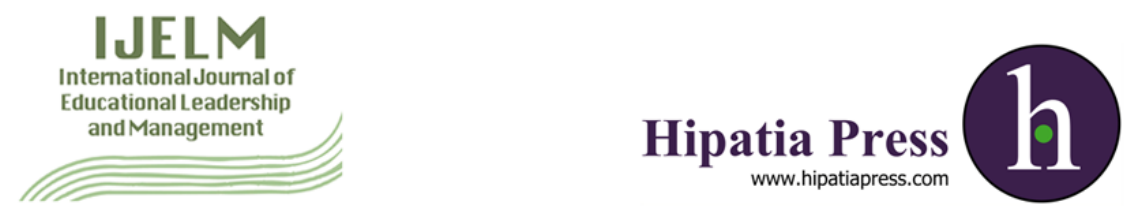

Instructions for authors, subscriptions and further details:

http://ijelm.hipatiapress.com

\title{
The Task of Reviewing and Finding the Right Organizational Change Theory
}

Abayomi Oluwatosin Alase ${ }^{1}$

1) Northeastern University, Boston, MA, USA

Date of publication: July $16^{\text {th }}, 2017$

Edition period: July 2017-December 2017

To cite this article: Alase, A. O. (2017). The Tasks of Reviewing and Finding the Right Organizational Change Theory. IJELM, 5(2), 198-215. doi: 10.17853/ijelm.2017.2631

To link this article: http://dx.doi.org/10.17583/ijelm.2017.2631

\section{PLEASE SCROLL DOWN FOR ARTICLE}

The terms and conditions of use are related to the Open Journal System and to Creative Commons Attribution License (CC-BY). 


\title{
The Task of Reviewing and Finding the Right Organizational Change Theory
}

\author{
Abayomi O. Alase \\ Northeastern University
}

\section{Abstract}

Organizational change is probably the singular most important undertaken that many organizations wish they could do to affect their productivities/profitability performances. This review paper will highlight some of the well-known theories and approaches to organizational change. In the late 1990s and early 2000s, America had one of the best economies in decades and many of her citizens were able to benefit from it both financially and educationally; the economy (and educational aspirations) grew expeditiously and lifted millions of Americans out of poverty. These economical and educational turnarounds were achieved due in part to innovative and transformational leaders who understand that in order for businesses to grow, organizational change has to be an integral part of the process. However, the issue now is that there seems to be too many complex and confusing change theories that profess to have the remedies for 'fixing' the organizational problems. Ideally, however, this review paper will try to highlight the essentials of the selected organizational change and leadership theories and simplify them by making them accessible and understandable. Additionally, this review will try to ease some of the confusions of the theories and potentially help guide the change agents to the appropriate organizational change theories.

Keywords: organizational change, change theory, change leadership, organizational leadership 


\title{
La Tarea de Revisar e Identificar la Teoría del Cambio Organizacional Correcta
}

\author{
Abayomi O. Alase \\ Northeastern University
}

\section{Resumen}

El cambio organizacional es probablemente el singular más importante emprendido que muchas organizaciones desean que pudieran hacer para afectar sus productividades / desempeño de rentabilidad. Este documento de revisión destacará algunas de las teorías y enfoques bien conocidos del cambio organizacional. A finales de los años noventa y principios de los años 2000, América tenía una de las mejores economías en décadas y muchos de sus ciudadanos podían beneficiarse de ella tanto financiera como educativamente; La economía (y las aspiraciones educativas) creció rápidamente y levantó a millones de americanos de la pobreza. Estos cambios económicos y educativos se lograron debido en parte a líderes innovadores y transformacionales que entienden que para que las empresas crezcan, el cambio organizacional debe ser una parte integral del proceso. Sin embargo, la cuestión ahora es que parece haber demasiadas teorías de cambio complejas y confusas que profesan tener los remedios para "arreglar" los problemas organizacionales. Idealmente, sin embargo, este documento de revisión tratará de poner de relieve lo esencial de las teorías de cambio organizativo y liderazgo seleccionadas y simplificarlas haciéndolas accesibles y comprensibles. Además, esta revisión tratará de aliviar algunas de las confusiones de las teorías y, potencialmente, ayudará a guiar a los agentes de cambio hacia las teorías de cambios organizacionales apropiadas.

Palabras clave: cambio organizacional, cambio de teoría, cambio de liderazgo, liderazgo organizacional 

$\Gamma$ he conceptualization of organizational change theories and approaches have been written and discussed for over 30 years with very little true mechanisms to use in turning organizations around. Some of the older theories are much simple and straight-forward in their approach to organizational changes (i.e. Lewin, 1947, theory on unfreezing, moving, and refreezing). However, the newer and more complex change theories are more theoretically based than practical. In this literature review, attempt will be made to organize and simplify many of the newer theories and approaches on organizational change to help develop an understanding of how the change concepts have evolved and broaden. The truth of the matter is that, there is a need for organizational change to re-conceptualize how to safely and practically implement changes in organizations without over-stressing and over-burden both the organizational structures and members of the organizations. In the past decade or so, we've seen corporations of various sizes and reputations go from prosperities to receiverships and/or bankruptcies, partly because of the unscrupulous and unethical leaderships who control those organizations. However, there are leaders who are equally concern about the volume of change theories that professes to have the 'cures' for organizations that are going through problems; the fact of the matter is that there are too many proliferations of untested and badly conceived change theories. The proverbial problem of statement questions that need to be asked is how and where can innovative and transformational leaders who are facing problems at their respective organizations find the right change theory (or approach) that will help turn their organizations around? Additionally, what exactly constitute a good change theory? This review will attempt to look into some of the established theories and highlight their potent quality and authenticity in the world of organizational change.

\section{The different types of organizational change theories}

The implementation of organizational change in a troubled company (or organization) might sound simplistic and easy to do, but the truth of the matter is that it is not; implementing any kind of change can be difficult and problematic for both the change agents who will be implementing the change and the personnel whose life is going to be touched and impacted by the change. The fact is that every organization that is properly managed has 
at its helm a dynamic and transformational leader. Therefore, if the right leadership is not there to create the atmosphere for lasting change, no amount of organizational changes would rectify the problems that the organization is going through. Therefore, the question now is how can an organization that is ready for change find the appropriate change mechanism? Van de Ven and Poole (1995) discussed the interplay of different ideologies and perspectives that can help draw a clear picture of what organizational change and development is all about. The fact is that no one discipline with a singular ideology can explain the full range of organizational change and development. However, with diverse disciplines and their worldviews on issues related to organizational change and development, Van de Ven and Poole (1995) stated that, that will "provides opportunities to develop new theory that has stronger and broader explanatory power than the initial perspectives" (p. 511). Explaining the difference among organizational change is perhaps the hardest thing to do because of the diversity among the organizational change theories and approaches. However, Ven de Van and Poole (1995) explained that "It is the interplay between different perspectives that helps one gain a more comprehensive understanding of organizational life, because any one theoretical perspective invariably offers only a partial account of a complex phenomenon" (p. 510-511). To illustrate the differences, they gave three approaches to explain how and why changes in organization occur. The first approach is basically four types of theories needed in organizational change:

- Life-cycle change theory described organization as a living organism. Even though organizations need to go through changes, the organizations nevertheless keep and maintain themselves throughout the change process.

- Teleological change theory basically explains that organization has a purpose and goals, and can be very adaptable. This theory also encourages cooperation among like-minded people when it comes to organizational change.

- Dialectical change theory encourages oppositions and conflicts between two or more distinct entities via mergers and/or take-over embattlements. Basically, dialectical theory is a theory that is complex and engaged in conflict. 
- Evolutionary theory is all about change. In this theory, no organization stays static. Change is on-going (continuous) and the organization has to be adaptable to new changes.

The second approach, according to Van de Ven and Poole (1995), is to "arrange these four ideal-type process theories into a typology by distinguishing the level and mode of change to which each theory applies" (p. 511). And finally, the third approach; this approach basically tries to analyze how useful the typology is to understanding the organizational change process.

In order to demystify the change process, Weick and Quinn (1999) came up with a way of highlighting the two different organizational change mechanisms. They stated that "The contrast between episodic and continuous change reflects differences in the perspective of the observer" (p. 362). The important thing to know about organization change is that change just doesn't appear out of thin air; it is a sort-after mechanism that is in demand because there are organizational problems that needed to be fixed and/or changed; as Czarniawska \& Joerges (1996) stated "First there were losses, then there was a plan of change, and then there was an implementation, which led to unexpected results" (p. 20). To explain the difference between the episodic and continuous change theories, Weick and Quinn (1999) gave the following definitions:

The phrase "episodic change" is used to group together organizational changes that tend to be infrequent, discontinuous, and intentional. The presumption is that episodic change occurs during period of divergence when organizations are moving away from their equilibrium conditions. Divergence is the result of a growing misalignment between an inertial deep structure and perceived environmental demands. (p. 365)

They then described continuous change, as "The phrase "continuous change" is used to group together organizational changes that tend to be ongoing, evolving, and cumulative" (p. 375). Both episodic and continuous change theories are theories that are very similar to the revolutionary and evolutionary change theories that Burke (2011) discussed in his 'organization change theory and practice' book. Episodic and revolutionary 
theories described a change mechanism that is wholistic in nature, and the continuous and evolutionary theories described a change mechanism that is applicable on continuous bases even in a well-managed organization.

\section{Open system theory and the environmental effects}

The theoretical premise behind organizational change is to find equilibrium within an organization vis-à-vis running a smooth production operation and making healthy profit for its stakeholders. The survivability of any business organization depends on an open-system theory and its characteristics and attractiveness to the external resources for energy (investments) sustainability. In an open-system theory, Burke (2011) reiterated that "Any human organization is best understood as an open system. An organization is open because of its dependence on and continual interaction with the environment in which it resides" (p. 56). For any organization to operate smoothly with little or no production slowdown, it is imperative that the organization look for resources (external energy sources) that would finance the purchase of needed raw materials and other expenditures. Money allows for organization to invest in itself; organizations, in today's market, need to be agile and competitive. In other words, every organization that wants to be relevant, need the external energy (external financial resources) to invest in capital expenditures that the organization need to have a fighting chance of survival.

According to Burke, there are three operative stages that are synonymous with survivability of any organization in an open system theory, they are the following:

- Input - The first stage is when the organization gets all of its resources (external investments, loans from the banks, etc.) for acquiring all the needed expenditures (i.e. raw materials, machineries, hiring of employees etc.).

- Transformation - This is the stage of conversion of raw material into finished products (the manufacturing stage).

- Output - This last stage is the shipping of the products to the general public to be sold for regeneration of resources back to the organization for continuous production. 
Open-system theory allows for a systematic recycling process in an organization to navigate its way around the market system for external source of investment. According to Burke (2011), he stated that "a bank loan (input) provide money to purchase raw materials (more input) so that a product can be made (transformation) and then sold (output) to consumers, and their payments provide money for further input, reactivating the cycle" (p. 56). In other words, it is a recycling mechanism that keeps a strong organization alive and running.

The concept of open system theory is basically the interaction between organizations and its environments; however, the impacts of environments on organizations are immeasurable to say the least. Davis and Powell (1992) discussed the relationship between organizations and their environments. Parts of their discussions were the three theoretical approaches that may be impacted by some environmental constraints. The three approaches are (1) Thompson's (1967) contingency theory, (2) Pfeffer and Sallancik's (1978) resource dependence theory, and (3) Williamson's (1975, 1981 and 1985) transaction costs economics (TCE) theory. Each of these approaches explains how the external factors have some impacts on the performances and functionalities of many organizations in the global marketplaces. A brief context on the three theories would help explain why the authors thought that the environmental factors would create uncertainty in the performance and function of an organization.

The first approach was Thompson's (1967) contingency theory; this theory saw organization as an open system with three levels of responsibilities and controls: (a) According to Thompson's theory, technical level must be controlled and sealed off from the outside; (b) The managerial level is seen as uncertain because of the mediation contact it has to negotiate between the technical level and the outside environment. And finally (c), the institutional level is believed to have the highest level of uncertainty, because it operates from an environment in which it has little or no control. The second approach was Pfeffer and Sallancik's (1978) theory of resource dependence; this theory was based on a premise that organizational behaviors can be explained by looking at the organization's context. Resource dependence theory believes that because the organization operates within a domain that is controlled by an external source, and also because it is an open system organization, it is at risks of external interference. Hence, it tries to secure enough resources to protect its 
survivability. The third approach was Williamson's (1975, 1981 and 1985) Transaction Costs Economics theory (TCE); the third theory (TCE) agenda was to monitor the economic conditions of the financial marketplaces to understand its volatility (the ups and downs trajectory of the marketplaces). According to Davis and Powell (1992), they alluded to the fact that "Several assumptions are critical for this approach" (p. 326). There are two behavioral factors that go with the assumptions: (a) the first assumption assumed that people have good intentions, but are limited in their financial resources, (b) and secondly, some people are perceived to be opportunistic even though it is hard to identify this people from the rest of the population.

\section{Organizational change theories in the educational setting}

Perhaps this is one of the untold myths about organizational change, many people believed that organizational change is only synonymous with business organizations alone; however, implementation of organizational change does have a major presence in the educational systems in North America. According to Hallinger (2003), a university professor and a former principal, he stated that for over 25 years, selecting and promoting principals in the United States school systems has largely and primarily been based on finding an instructional leaders; someone who can lead by showing that he/she has the capacity to supervise, control, coordinate and develop curriculum for schools. However, the leadership preference shifted to transformational leadership in the 1990s when school principalship positions were reversed from top-down position to bottom-up leadership style. As a transformational leader, principals would exemplify a bottomup leadership approach, a second-order target for change approach, and have the ability to show a people-orientation (transformational) leadership skill toward the teaching staff and clientele. However, Hallinger (2003) described the instructional leadership principals as leaders who would manage from the top-down approach, using the first-order leadership approach and manage in a transactional style.

Hargreaves (2009) moved the educational change theory forward by conceptualizing a new educational change theory that he called the fourth way based on "five-pillar" concept. These five-pillar concept is partially based on the three previous systems that were in operation in North America, and partially based on international components that have being 
tested and proven to work in the nomadic countries of Europe. According to Hargreaves (2009), he stated that the pillars are "A viable theory-inaction of educational change must rest on the basic principles of sustainability" (p. 22). A brief description of the pillars according to Hargreaves:

- Pillar 1: An inspiring and inclusive vision: This pillar is about the moral and inspiration of change. Change that encourages team-work and selflessness - Hargreaves (2009) stated that "An inspiring and inclusive moral purpose steers a system, bind together, and draws the best people to work in it" (p.23).

- Pillar 2: Public engagement: According to Hargreaves (2009), he stated that "The purposes that define a society's future vision are not for governments or their educational advisors to decide. They are a matter for public engagement and for leaders who can tap into and elevate the public's spirit" (p. 24).

- Pillar 3: No achievement without investment: Couple of years ago, we saw the increase in partnership between the state/local governments and the school districts, helping to create opportunities for children of underprivileged families in our society. However, that sense of partnership has shifted to a state of normlessness by some of the state/local governments. The fact of the matter is that without reasonable and sustainable investments in the school systems, it is almost impossible to achieve the goals that the government set out. Therefore, it is important for the stakeholders to know that investment is very important to the education of our children

- Pillar 4: Corporate educational responsibility: The environment is gradually changing to involve the American corporations in the education of our children. Hargreaves (2009) stated that "The environmental movement has shifted many corporations' sense of responsibility. More and more businesses now practices corporate social responsibility" (p. 26). 
- Pillar 5: Students as partner in change: Hargreaves (2009) stated that "Students are usually the targets of change efforts and services; they are rarely change partners. But students are highly knowledgeable about the things that help them learn, such as teachers who know their material, care for them, have a sense of humor, and never give up on them" (p. 27)

\section{The different types of organizational leadership}

In order for organizational change to take root in the fabric of everyday activities of organizations, it has to be done under the leadership of someone who is dynamic and innovative (i.e., transformational-charismatic and change leaderships); these two leadership styles can transform and efficiently implement any needed organizational changes. Burnes and By (2011) discussed how for the past 30 years, leadership and change has been synonymous with organizational change in the corporate world. At the beginning, organizational leadership was based on the idea of someone whom the organization could see as been in control; a top-down executive with power. However, with too much power come ethical issues and problems. Thus ushered in the charismatic-transformational leader; someone who is bottom-up leader. A leader who has the charisma and selfconfidence to engage his/her staff in decision making processes; and a leader who is ethical and willing to lead by example.

Organizational change and change leadership are concepts that try to find a balance between change and the change agents. Krysinski and Reed (1994) suggested that systemic change is an unpredictable fluid rotational change that can take approximately four phases and many years in-between to accomplish. According to Krysinski and Reed (1994), the first phase would be the stage that will build on the awareness and identification for change. The second phase will be the time to start training and implementing the change processes. The third and fourth phases will be the time to monitor the change plan. Krysinski and Reed also discussed the three critical occurrences that can happen during the change implementations. The first is the involvement of the CEO in the change project. The advocacy and involvement of the CEO of the organization is vitally important in pushing ahead the likelihood and possibility of the change ever being implemented. The second is the shared meaning. 
Shared meaning basically means that all the parties involved are sharing what it means to them for the change project to be implemented. And finally, the third is the uncertainty that comes with change. In essence, the uncertainty, anxiousness, and the ambivalence that occurs when organizational change converged on the employees.

Change leadership concept is when leaders commit to a change and actually stand-by and implement the change. These kinds of leaders tend to have the charisma to influence employees. There are two types of leaders with these kinds of leadership pedigrees. According to Krysinski and Reed, the first is a leader with authority mode; these kinds of leaders are charismatic and traditional, they have the ability and charisma to influence others to follow their directives. The second types of leadership are leaders who utilize power as a means to influencing others. This is a leader who influence via the power mechanism; this is a leader who uses rewards and sanctions to get their way.

Herold, Fedor, Caldwell \& Liu (2008) described the transformational leadership style as a leader who is more compassionate and understanding of the employees' needs. And on the other hand, they depicted the change leadership as a leader who is an ultimate change agent. Someone whose job it is to go into a dysfunctional organization and get the problem fixed, with minimal or no real input from the employees' in terms of their needs and concerns been taken into consideration. Though, both leadership styles were said to be efficient and capable of getting the job done; however, the idea behind the study was to see which of the two leadership styles will win the commitments of the employees. Naturally, it would seem as though the employees would follow the transformational leader, someone who is more compassionate than the change leader who is task oriented. However, what the study discovered was that, even though the employees would like to have followed the transformational leader under normal circumstances, the study showed that they would not hesitate to follow the change leader if he/she could moderate his/her positions and behaviors. That goes to show that organizational change and leadership styles need the commitment and cooperation of the employees before any meaningful change/changes can be accomplished. Therefore for organizational change to be successful in any organization, it is imperative for both the transformational and change leaderships (especially change leadership) to moderate their positions and 
behaviors vis-à-vis the employees' needs and concerns in order for the leadership to get the employees' commitments.

\section{The effects of organizational change on humans}

To better understand the effects of organizational change on humans, Chin and Benne (1985) dig deeper into the strategies that affect change in human systems. As they elaborated on their strategies, they categorized them into three groups and in each group there were series of strategies that were discussed. The first group was labeled Empirical-Rational Strategies. The premise behind these groups is based on the belief that people are rational and naturally will follow their rational self-interest once they understand that it is in their best interest to do so.

Under the first category of Chin and Benne's (1985) there are six strategies, and the following brief descriptions explain each strategy: (1) the first strategy is about dissemination of knowledge to the people for understanding and approval, so that they can act on it; (2) the second strategy is about replacing the wrong people who are in a position that they were not supposed to be in; (3) the third strategy is about system analyst using computer to deliver knowledge in a rational and systematic way; (4) the fourth strategy basically believed that sound research should be used to promote change; (5) the fifth strategy is basically an utopian (fantasy) belief-system that believed that change can make the society a better place for all (a better future for the society); and finally (6), the sixth strategy basically suggested that in order to dissolve or disarm any potential enemy, the best thing to do is to purify the language. The idea behind this strategy is to allow experts to see things clearly; communicate clearly with fewer barriers, and finally be able to reason with commonality.

The second category of Chin and Benne's (1985) human system is called the Normative-Re-educative Strategies. This category basically has two strategies in it: (1) the first strategy is about problem solving capacities of the human system; (2) and the second strategy is about putting people first (the growth of an individual takes precedence over any and everything else).

Finally, the third category of Chin and Benne's (1985) human system is labeled Power-Coercive Strategies. This category is primarily based on using power in all ways possible, and it comes with three strategies: (1) the 
first strategy is using power in a non-violent way; (2) the second strategy is basically about using political and governing power in the society; and finally, (3) the third strategy is to reconstitute the power structure in favor of the less-privileged (or the less powerful) in the society, like been a member of an organized union. The interesting fact is that the true human effects brought on by organizational change have never been truly studied to understand the impacts and ramifications of organizational change on human beings.

There have been studies done to investigate the reason why there are employees' dissatisfactions and resistances in organizational change. Perhaps the reason why there are resistance and ambivalence by employees toward organizational change is not necessarily because the employees are not committed to change, but because organizational change, itself, can be unpredictably stressful and damaging, especially on the employees who work for those organizations. Piderit (2000) weighted on the side of the employees when she stated that "Successful organizational adaptation is increasingly reliant on generating employee support and enthusiasm for proposed changes, rather than merely overcoming resistance" (p. 783). As a matter of fact, many of the organizational change writers have come to the realization that not every employee resistance is counterproductive and anti-change. The most important thing that the change agents and change writers have to understand and take into consideration is the fact that both the employees and the organizations need each other. The fact is that employees need organizations just as much as the organizations need the employees. Employees need a place to go to fulfill their days' worth of work and at the end of the day, take home their earnings to feed their families. On the other side, the organizations need the productivity of their innovative and energetic employees to work hand in hand and as partners in moving forward the overarching mission statement of the organization. Hence the reasons why both parties need to recognize that they need each other as much as the shareholders need the organizations to be profitable.

\section{Summary}

This review tries to give a clear picture of the different organizational change theories that are out there, including the educational change and 
leadership theories. These reviews were centered on theories believed to be practicable and implementable. Though many theories have been theorized and professed to be a 'cure-all' theory for any organizational problems, however, many of these theories have been found to be practically unworkable. Many studies have come to the conclusion that over half of the change theories have a failure rate, hence the reason why many change agents are confused and frustrated with many of the change theories and approaches that are out there; many of these change agents don't know what works and what doesn't. In this review, several change theories were discussed and reviewed. These theories include the life-cycle, teleological, dialectical, and evolutionary that Van de Ven and Poole (1995) discussed. Then comes the episodic and continuous organizational change theories discussed by Weick and Quinn (1999). These theories were similar to the change theories (revolutionary and evolutionary) that Burke (2011) discussed in his book called 'Organization Change theory and practice'. These change theories were meant to infuse a wholistic and systematic change in an organization. The first change theories (revolutionary and episodic) are theories that can literarily and completely transform an organization in an wholistic way, while the second change theories (evolutionary and continuous) emphasizes a continuous change even in a profitable and well run organizations.

However, to have a truly viable organization that change mechanism can improve, the organization requires an open system theory. Open system organizations dependent on a continual interaction with the external environments in which it resides and operate from. Burke (2011) laid out the systemic way that an open system organization operates. He discussed the input, transformation, and output operational system in an open system organization, and the importance of external resources (outside investments and the environments that it operates out of). To fully understand the extent of external impacts on organizations, Davis and Powell (1992) gave three examples of theoretical approaches: (a) Thompson's (1967) contingency theory, (b) Pfeffer and Sallancik's (1978) resource dependence theory, and (c) Williamson's (1975, 1981 and 1985) transaction costs economics (TCE) theory. However, looking at organizational change from an educational setting change perspective, Hallinger (2003) alluded to the fact that for over 25 years, selecting and promoting principals in the United States school systems has largely been based on finding an instructional leader. $\mathrm{He}$ 


\section{Alase-Organizational Change Theory}

alluded to the fact that leadership preference shifted to the transformational leadership in the 1990s when school principalship positions were reversed from top-down to bottom-up leadership style. To improve the educational systems in North America, Hargreaves (2009) came up with the five-pillar change concept that is partially based on the three previous educational systems in North America, and infused with an international component that is tested and proven in the nomadic countries of Europe. This change theory emphasizes and deliberates on the sustainability of the North American educational systems for the long haul.

The change leadership is another leadership theoretical concept that is based on leaders who are committed to change. These kinds of leaders tend to have the charisma and fortitudes to lead and influence the employees through involvement of the employees in the change process. According to Krysinski and Reed (1994), there are two types of leaders with these kinds of leadership pedigrees, the first is a leader with authority mode; these kinds of leaders are leaders who have the charismatic and traditional ability to influence others to follow their leads and directives. The second types of leadership are leaders who utilize power as a means to influence others; this second kind of leaders influences the employees via the power mechanism which is a reward and sanction mechanisms to get the employees to follow their leads. Herold, Fedor, Caldwell \& Liu (2008) described the transformational leadership style as a leader who is more compassionate and understanding of the employees' needs. On the other hand, they described the change leader as someone who is an ultimate change agent; someone whose job it is to go into a dysfunctional organization and get the problem fixed. To further strategize the impacts of organizational change on humans, Chin and Benne (1985) came up with the following three theories: The first is called Empirical-Rational Strategies: the premise behind this category is based on the belief that people are rational and naturally people will follow their rational self-interest once they understand that it is in their best interest to do so. The second is called Normative-Reeducative Strategies: this category basically has two strategies in it: (a) problem solving capacities of the human system; (b) putting people first before anything else. And the third theory is called Power-Coercive Strategies: This category is primarily based on using power in all and any way possible and it comes with three strategies: (a) using power in a nonviolent way; (b) using political and governing power in the society; and (c) 
is to reconstitute the power structure in favor of the less-privileged in the society.

Finally, Piderit (2000) discussed the issue of employee resistance at workplaces. As humans, every human being has as their primary responsibility the welfare of their families; therefore any organizational change that is going to impact that reality is going to encounter some kind of resistance if the employees are not involved in the change process. As such, Piderit (2000) said it best when she stated that "Successful organizational adaptation is increasingly reliant on generating employee support and enthusiasm for proposed changes, rather than merely overcoming resistance" (p. 783)

\section{Conclusion}

In conclusion, it is true that there are too many organizational change and leadership theories that seem to come out every time you pick up an organizational change and leadership journal articles. Additionally, there seems to be no shortage of theories that professes to have the key mechanism for organizational change solution. However, many of these theories have been found to be impracticable and plainly unworkable. Many of the change theories are contradictory and un-implementable; the failure rates of these theories make the implementation of organizational change confusing and frustrating for many of the organizations and their leadership teams (Balogun and Hope-Hailey, 2004; Burnes, 2004; Doyle, 2002; Edmonstone, 1995; Guimaraes and Armstrong, 1998).

The fact of the matter is that many of the organizational change theories that are out there have no theoretical base to stand on. Moreover, many of them are personal intuitions and assumptions that the authors of the theories turned into theories without proper research to back up the findings and results. Therefore, as it is in any life endeavors, practical and research experience of these authors (theorists) should be taken into consideration before their articles are published. However, the question that needs to be asked is how can the organizations find the right organizational change theory that is implementable and workable for them? Well, in my opinion, many of the above reviewed theories are well-researched and proven theories that are practicable and workable. Even though not every theory 
work the same way in every organizations, however, the above theories seem to have been thoroughly researched and vetted for applicability. In any case, many of the above theories can be used as a 'starting point' in any organizational change process, and if it doesn't work to the satisfaction of the change agents, another one can be tried until the right one is found.

\section{References}

Balogun, J., \& Hope-Hailey, V. (2004). Exploring strategic change. London: Prentice Hall.

Burke, W. W. (2011). Organization change: Theory and practice. Thousand Oaks, CA: Sage. 55-72

Burnes, B. (2004). Managing change: A strategic approach to organizational dynamics. Harlow: Prentice Hall.

Burnes, B., \& By, R. T. (2011). Leadership and changer: The case for greater ethical clarity. Springer Science+Business Media B.V.

Chin, R., \& Benne, K. D. (1989). General strategies for effecting changes in human systems. In W. G. Bennis, K. D. Benne, \& R. Chin (Eds.), The planning of change (4th ed., pp. 22-45). Fort Worth, TX: Harcourt Brace Jovanovich College Publishers.

Czarniawska, B. \& Joerges, B. (1996). Travels of ideas. In Czarniawska, B. \& Sevon, G. (Eds.). Translating Organizational Change. NY: Walter de Gruyter.

Davis, G. F., \& Powell, W. W. (1992). Organization-environment relations. Handbook of industrial and organizational psychology, 3, 315-375.

Doyle, M. (2002). From change novice to change expert: Issues of learning, development and support. Personnel Review. 31(4), 465-481.

Edmonstone, J. (1995). Managing change: an emerging consensus. Health Manpower Management. 21(1), 16-19.

Guimaraes, T., \& Armstrong, C. (1998). Empirically testing the impact of change management effectiveness on company performance. European Journal of Innovation Management. 1(2), 74-84.

Hallinger, P. (2003). Leading educational change: reflections on the practice of instructional and transformational leadership. Cambridge Journal of Education. 33(3) 
Hargreaves, A. (2009). The fourth way of change: Towards an age of inspiration and sustainability. In A. Hargreaves \& M. Fullan. Change war (pp. 11-43). Bloomington, IN: Solution Tree.

Herold, D., Fedor, D., Caldwell, S. \& Liu, Y. (2008). The effects of transformational and change leadership on employees' commitment to change: A multiple study. Journal of Applied Psychology. 92 (2), 346-357.

Krysinski, P. R., \& Reed, D. B. (1994). Organizational change and change leadership. The Journal of Leadership Studies. 1(2)

Lewin, K. (1947). Group decision and social change. In T. M. Newcomb, E. L. Hartley, et al. (Eds.), Readings in social psychology (pp. 330-344). New York: Henry Holt.

Pfeffer, J., \& Salancik, G. R. (1978). The external control of organizations: A resource dependence perspective. New York: Harper \& Row.

Piderit, S. K. (2000). Rethinking resistance and recognizing ambivalence: A multidimensional view of attitudes toward an organizational change. Academy of Management Review. 25(4), 783-794.

Thompson, J. D. (1967). Organizations in action. New York: McGraw-Hill. Van de Ven, A., \& Poole, M. (1995). Explaining development and change in organizations. Academy of Management Review. 30, 510-540

Weick, K. E., \& Quinn, R. E. (1999). Organizational change and development. Annual Review of Psychology. 50, 361-386.

Williamson, O. E. (1975). Markets and hierarchies: Analysis and antitrust implications. New York: Free Press

Williamson, O. E. (1981). The economics of organization: The transaction cost approach. American Journal of Sociology. 87, 548-577.

Williamson, O. E. (1985). The economic institutions of capitalism: Firms markets, relational contracting. New York: Free Press.

Abayomi O. Alase (Northeastern University, Boston, MA, USA)

Address: 600 Medary Avenue, South, Brookings, SD 57006, USA.

Email: aalase@yahoo.com, samuel-alase.a@husky.neu.edu 